\title{
THE FREQUENCY OF INFECTIOUS COMPLICATIONS BETWEEN MECHANICAL BOWEL PREPARATION AND NO PREPARATION IN ELECTIVE COLONIC SURGERY.
}

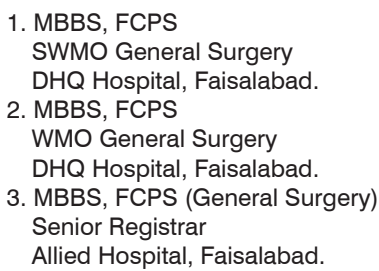

Correspondence Address:

Dr. Sabeen Adil

Department of General Surgery

DHQ Hospital, Faisalabad.

ssabeen78@gmaill.com

Article received on: 17/05/2019

Accepted for publication:

$15 / 10 / 2019$

\begin{abstract}
Sabeen Adil', Faiqa Aslam², Muhammad Usman ${ }^{3}$
ABSTRACT: Mechanical bowel preparation (MBP) is the cleansing technique used clean up the large gut using oral cathartic agents like polyethylene glycol, sodium phosphate, sodium Pico sulfate, and magnesium citrate. Objectives: To compare the frequency of infectious complications between mechanical bowel preparation and no preparation in elective colonic surgery. Study Design: Randomized control trial. Setting: OPD or Indoor Surgical unit 5, DHQ Hospital, Faisalabad. Period: $1^{\text {st }}$ January 2017 to $31^{\text {st }}$ Dec 2018. Material \& Methods: Patients diagnosed of malignant tumors of colon, appendix or cecum were included in study. Group A: mechanical bowel preparation done according to standard protocols, group B no mechanical bowel preparation was done. All patients were followed regularly for 2 weeks for presence or absence of surgical site infections and anastomotic leakage. Results: In this study, surgical site infection in both groups was compared, it shows that $18.59 \%(n=37)$ in Experimental group and $9.55 \%(n=19)$ in Control group had SSI while $81.41 \%(n=162)$ in Experimental group and $90.45 \%(n=180)$ in Control group bad no SSI, $p$ - value was calculated as 0.009 showing a significant difference. Comparison of surgical anastomotic leakage in both groups was done, it shows that $2.51 \%(n=5)$ in Experimental group and $1.51 \%(n=3)$ in Control group had anastomotic leakage, $p$ - value was calculated as 0.47 showing insignificant difference. Conclusion: We concluded that no mechanical bowel preparation is significantly better than mechanical bowel preparation in elective colonic surgery in terms of post-operative surgical site infection.
\end{abstract}

Key words: Elective Colonic Surgery, Mechanical Bowel Preparation, Post-operative Surgical Site Infection.

Article Citation: Adil S, Aslam F, Usman M. The frequency of infectious complications between mechanical bowel preparation and no preparation in elective colonic surgery. Professional Med J 2020; 27(3):594-600.

DOI: 10.29309/TPMJ/2020.27.3.3723

\section{INTRODUCTION}

Surgical site infection (SSI) is a common presentation of patients undergone elective large gut surgery. It can be a mild lesion or it could be a deep abscess in the cavity or on the abdominal wall. ${ }^{1}$ Patients sometime may even need a reoperation followed by prolonged hospitalization, with re-admission in the ICU with management. These infections further increases the treatment cost and morbidity due to operation. ${ }^{2,3}$

Mechanical bowel preparation (MBP) is the cleansing technique used clean up the large gut using oral cathartic agents like polyethylene glycol, sodium phosphate, sodium Pico sulfate, and magnesium citrate. ${ }^{4}$ Although this practice before every large gut surgery has become a major requirement and colorectal anastomosis is at risk of infection in gut with fecal matter.

Mechanical bowel preparation may decrease the intra luminal content of bacteria thus decreasing intra-operative leakage of gut contents with millions of bacteria to reach and cause peritonitis. Mechanical gut preparation have no risk of bacterial leakage out of the gut, but only if gut wall is disrupted. ${ }^{5}$ Although it is safe but it can lead to nausea, abdominal pain, and even diarrhea, thus leading to disturbance in electrolytes and dehydration further complicating the induction phase of anesthesia and preoperative care. ${ }^{8}$

A recent research done by Asis Kumar suggests that 'Not' preparing gut before surgery have no 
disturbance in anastomosis strength with no increased chances of leakage. In this study wound infection was seen in $12 \%$ versus $11 \%$ cases with and without bowel preparation, respectively. ${ }^{6}$ Another study done by Stefano Scabini ${ }^{7}$, rate of infectious complications were found to be $20.0 \%$ after mechanical preparation of bowel versus $11.0 \%$ after no preparation in colonic surgery.

As there is controversy between results of recent research work regarding impact of omission of mechanical bowel preparation on frequency of complications like infections occurring after the operation, so the Rationale of my study is to conduct a randomized controlled trial to compare the frequency of infectious complications between mechanical bowel preparation and no preparation in elective colonic surgery. So that I can justify my results in a way that either omission of mechanical bowel preparation makes a difference in terms of reducing infectious complications or it will make no difference at all. If appropriate results are seen, it should be recommended as a regular common practice thus reducing hospital cost through reduction of post-operative infectious complications.

\section{PATIENTS AND METHODOLOGY}

Patients were included for our randomized control trial from the surgical floor of $\mathrm{DHQ}$ Hospital Faisalabad within 6 months once it was approved from hospital ethical review committee. Patients of both genders aging between 15 to 75 years presented in OPD having indications for elective colonic surgery for following colonic diseases: Malignant Tumors of right or left side of colon and Malignant Tumors of appendix or cecum.

Surgical Site Infections (SSIS) was defined according to center for disease control (CDC) classification .Superficial (SSIS) was defined as an infection involving only skin and subcutaneous tissues. Deep (SSIS) was defined as an infection that involves deep fascia or muscles and require debridement. Anastomotic leakage can be detected on clinical or radiological findings having clinical feature of fecal drainage through per anastomotic drain and radiological diagnosis was defined as leakage in cases of suspected leak was made through contrast enhanced CT scan. On CT Anastomotic leakage was detected by air fluid collection at anastomotic site.

Patients with abdominal abscess seen at time of operation, on oral or inject able anti-coagulants or corticosteroid (assessed on history). Immuno compromised patients (assessed on medical record).Patients having any allergy or known contraindication to polyethylene glycol (assessed on history) and those who present with local skin site infections (assessed or clinical examination.

Sample size of 398 calculated using WHO sample size calculator with 5\% margin of error ,80\% power of study, taking percentage of surgical site infection after mechanical bowel preparation as $20.0 \%$ [8] and percentage of surgical site infection after no mechanical bowel preparation as $11.0 \%{ }^{8}$

All the patients were explained the details of the study and written informed consent was taken. Patients were admitted through OPD and diagnosed cases of malignant tumors of colon, appendix or cecum were included in study. All patients were randomized by using computer generated random number table. Group A included cases in which mechanical bowel preparation was done according to standard protocols. Clear liquid diet was started a day before surgery as a part of dietary modification and oral polyethylene glycol solution was given on evening (12-16) hours before surgery. In patient included in group B MBP was not done.

Demographic variables were obtained. Contact number of patients was taken for follow up. Patients were enquired about any drug allergy. General examination, systemic examination and assessment of airway were done. Baseline investigations including hemoglobin, serum blood sugar, and hepatitis $B$ and $C$ markers was done in pathological lab of DHQ Hospital Faisalabad and reported by the pathologist. $3 \mathrm{ml}$ blood for $\mathrm{CBC}$ and $3 \mathrm{ml}$ for the rest was taken. All samples were taken by staff nurse on duty. All patients were given premedication tablet Diazepam $10 \mathrm{mg}$ to alleviate anxiety and for sound sleep. All patients were given antibiotics 
1 hour before surgery, ceftriaxone $2 \mathrm{gm}$ O.D and metronidazole 500mg TDS and was continued for 2 days postoperatively. Surgery was done by consultant surgeons of SU (IV).

All patients were followed regularly for 2 weeks for presence or absence of surgical site infections and anastomotic leakage (as per-operational definition). Findings or outcome were seen either clinically or through radiological means like contrast enhanced CT scan (as per operational definition). All variables were noted on predesigned Proforma by principal investigator.

Data was analyzed using SPSS version 22.0. Mean and standard deviation for quantitative variables including age and BMI, while frequency and percentage was calculated for qualitative variable like gender, diabetes mellitus (present/ no), type of operation (hemicolectomy, subtotal Colectomy/transverse Colectomy/ sigmoidectomy / colostomy reversal) surgical site infections (present/no) and anastomotic leakage(present/no). Chi Square was applied to compare the frequency of surgical site infection and anastomotic leakage. $P$ - value $\leq 0.05$ was considered as significant.

Effect modifiers like age, gender, BMI (obese/ non-obese), type of operation (hemicolectomy /subtotal Colectomy/transverse Colectomy/ sigmoidectomy / colostomy reversal) and diabetes mellitus (present/no) were controlled through stratification and post-stratification chi square was applied to see their effect on outcome. $P$ - value $\leq 0.05$ was considered as significant.

\section{RESULTS}

Total 398 cases (199 in each group) fulfilling criteria were included in the study. Age distribution shows that $62.81 \%(n=125)$ in Experimental group and $59.80 \%(n=119)$ in Control group were between $15-50$ years of age while $37.19 \%(n=74)$ in Experimental group and $40.20 \%(n=80)$ in Control group were between $51-75$ years of age, mean $\pm S D$ was calculated as $45.98 \pm 13.36$ years in Experimental group and $47.52 \pm 13.21$ years in Control group.
Gender distribution shows that $44.72 \%(n=89)$ in Experimental group and $48.24 \%(n=96)$ in Control group were male whereas $55.28 \%(n=110)$ in Experimental group and $51.76 \%(n=103)$ in Control group were females.

Mean BMI of the patients was calculated as $28.52 \pm 5.74$ in Experimental group and $29.41 \pm 4.52$ in Control group. Frequency of diabetes mellitus in both groups was recorded as $22.61 \%(n=45)$ in Experimental group and $39.20 \%(n=78)$ in Control group whereas $77.39 \%(n=154)$ in Experimental group and $60.80 \%(n=121)$ in Control group had no diabetes mellitus. (Table-I)

\begin{tabular}{|c|c|c|c|c|}
\hline $\begin{array}{c}\text { Diabetes } \\
\text { Mellitus }\end{array}$ & \multicolumn{2}{|c|}{$\begin{array}{c}\text { Experimental } \\
\text { Group(n=199) } \\
\text { No. of } \\
\text { Patients }\end{array}$} & \multicolumn{2}{c|}{$\begin{array}{c}\text { Control Group } \\
\text { (n=199) }\end{array}$} \\
\hline No. of & \% & Patients & $\%$ \\
\hline Present & 45 & 22.61 & 78 & 39.20 \\
\hline Not present & 154 & 77.39 & 121 & 60.80 \\
\hline Total & 199 & 100 & 199 & 100 \\
\hline Table-l. Frequency of diabetes mellitus in both \\
groups (n=398)
\end{tabular}

Frequency of type of operations in both groups was recorded as $24.62 \%(n=49)$ in Experimental group and $20.60 \%(n=41)$ in Control group had hemicolectomy, $25.13 \%(n=50)$ in Experimental group and $23.62 \%(n=47)$ in Control group had subtotal colectomy, $18.09 \% \quad(n=36)$ in Experimental group and $18.09 \% \quad(n=36)$ in Control group had transverse colectomy, $13.06 \%$ $(n=26)$ in Experimental group and $19.10 \%$ $(n=38)$ in Control group had sigmoidectomy while $19.10 \%(n=38)$ in Experimental group and $18.59 \%(n=37)$ in Control group had colostomy reversal. (Table-II.)

\begin{tabular}{|l|c|c|c|c|}
\hline Type of Operation & \multicolumn{2}{|c|}{$\begin{array}{c}\text { Experimental } \\
\text { Group (n=199) }\end{array}$} & \multicolumn{2}{c|}{$\begin{array}{c}\text { Control Group } \\
(\mathbf{n = 1 9 9 )}\end{array}$} \\
\cline { 2 - 5 } & $\begin{array}{c}\text { No. of } \\
\text { Patients }\end{array}$ & $\%$ & $\begin{array}{c}\text { No. of } \\
\text { Patients }\end{array}$ & $\%$ \\
\hline Hemicolectomy & 49 & 24.62 & 41 & 20.60 \\
\hline Subtotal Colectomy & 50 & 25.13 & 47 & 23.62 \\
\hline Transverse Colectomy & 36 & 18.09 & 36 & 18.09 \\
\hline Sigmoidectomy & 26 & 13.06 & 38 & 19.10 \\
\hline Colostomy reversal & 38 & 19.10 & 37 & 18.59 \\
\hline Total & 199 & 100 & 199 & 100 \\
\hline $\begin{array}{r}\text { Table-II. Frequency of type of operations in both } \\
\text { groups (n=398) }\end{array}$ & \\
\hline
\end{tabular}


Comparison of surgical site infection in both groups was done, it shows that $18.59 \%(n=37)$ in Experimental group and $9.55 \%(n=19)$ in Control group had SSI while $81.41 \%(n=162)$ in Experimental group and $90.45 \%(n=180)$ in Control group bad no SSI, p - value was calculated as 0.009 showing a significant difference. (TableIII).

\begin{tabular}{|l|c|c|c|c|}
\hline \multirow{1}{*}{ SSI } & \multicolumn{2}{|c|}{$\begin{array}{c}\text { Experimental } \\
\text { Group (n=199) }\end{array}$} & \multicolumn{2}{c|}{$\begin{array}{c}\text { Control Group } \\
(\mathbf{n = 1 9 9 )}\end{array}$} \\
\hline & $\begin{array}{c}\text { No. of } \\
\text { Patients }\end{array}$ & $\%$ & $\begin{array}{c}\text { No. of } \\
\text { Patients }\end{array}$ & $\%$ \\
\hline Present & 37 & 18.59 & 19 & 9.55 \\
\hline Not present & 162 & 81.41 & 180 & 90.45 \\
\hline Total & 199 & 100 & 199 & 100 \\
\hline
\end{tabular}

Table-III. Comparison of surgical site infection in both groups $(n=398) P$ - value $=0.009$

Comparison of surgical anastomotic leakage in both groups was done, it shows that $2.51 \%(n=5)$ in Experimental group and $1.51 \%(n=3)$ in Control group had anastomotic leakage while $97.49 \%(n=194)$ in Experimental group and $98.49 \%(n=196)$ in Control group bad no anastomotic leakage, $p$ - value was calculated as 0.47 showing insignificant difference. (Table-IV).

\begin{tabular}{|l|c|c|c|c|}
\hline Anastomotic & \multicolumn{2}{|c|}{$\begin{array}{c}\text { Experimental } \\
\text { Group (n=199) }\end{array}$} & \multicolumn{2}{c|}{$\begin{array}{c}\text { Control Group } \\
\text { (n=199) }\end{array}$} \\
\hline Leakage & $\begin{array}{c}\text { No. of } \\
\text { Patients }\end{array}$ & $\%$ & $\begin{array}{c}\text { No. of } \\
\text { Patients }\end{array}$ & $\%$ \\
\hline Present & 5 & 2.51 & 3 & 1.51 \\
\hline Not present & 194 & 97.49 & 196 & 98.49 \\
\hline Total & 199 & 100 & 199 & 100 \\
\hline Table-IV. Comparison of anastomotic leakage in both \\
groups (n=398)
\end{tabular}

Effect modifiers like age, gender, BMI (obese/ non-obese), type of operation (hemicolectomy /subtotal Colectomy/transverse Colectomy/ sigmoidectomy / colostomy reversal) and diabetes (present/not present) were controlled through stratification and post-stratification chi square was applied. (Table-V to XIV)
Age: $15-50$ years

\begin{tabular}{|l|c|c|c|}
\hline \multirow{2}{*}{ Group } & \multicolumn{2}{|c|}{ SSI } & \multirow{2}{*}{ P-Value } \\
\cline { 2 - 3 } & Present & Not Present & \\
\hline A & 27 & 98 & 0.002 \\
\hline B & 9 & 110 & \\
\hline
\end{tabular}

AGE: $51-75$ years

\begin{tabular}{|l|c|c|c|}
\hline \multirow{2}{*}{ Group } & \multicolumn{2}{|c|}{ SSI } & P-Value \\
\hline A & Present & Not Present & \multirow{2}{*}{0.85} \\
\hline B & 10 & 64 & 70 \\
\multicolumn{2}{|c|}{ Table-V. Stratification for surgical site infection with } \\
regards to age $(\mathbf{n = 3 9 9 )}$
\end{tabular}

\section{Male}

\begin{tabular}{|l|c|c|c|}
\hline \multirow{2}{*}{ Group } & \multicolumn{2}{|c|}{ SSI } & P-Value \\
\hline A & Present & Not Present & \\
\hline B & 16 & 73 & 0.08 \\
\hline
\end{tabular}

\section{Female}

\begin{tabular}{|c|c|c|c|}
\hline \multirow{2}{*}{ Group } & \multicolumn{2}{|c|}{ SSI } & P-Value \\
\hline & Present & Not Present & \multirow{3}{*}{0.05} \\
\hline$A$ & 21 & 89 & \\
\hline B & 10 & 93 & \\
\hline \multicolumn{4}{|c|}{$\begin{array}{c}\text { Table-VI. Stratification for surgical site infection with } \\
\text { regards to gender }(n=399)\end{array}$} \\
\hline
\end{tabular}

\section{Present}

\begin{tabular}{|l|c|c|c|}
\hline \multirow{2}{*}{ Group } & \multicolumn{2}{|c|}{ SSI } & \multicolumn{1}{l|}{ P-Value } \\
\cline { 1 - 3 } & Present & Not Present & \\
\cline { 1 - 3 } A & 9 & 36 & 0.04 \\
\hline B & 6 & 72 & \\
\hline
\end{tabular}

\section{Not Present}

\begin{tabular}{|l|c|c|c|}
\hline \multirow{2}{*}{ Group } & \multicolumn{2}{|c|}{ SSI } & P-Value \\
\hline A & Present & Not Present & \multirow{2}{*}{0.08} \\
\hline B & 28 & 126 & \\
\hline \multicolumn{2}{|c|}{ Table-VII. Stratification for surgical site infection with } \\
regards to diabetes mellitus (n=399)
\end{tabular}

\section{Obesity}

\begin{tabular}{|l|c|c|c|}
\hline \multirow{2}{*}{ Group } & \multicolumn{2}{|c|}{ SSI } & P-Value \\
\cline { 2 - 3 } & Present & Not Present & \\
\hline A & 6 & 28 & 0.50 \\
\hline B & 5 & 36 & \\
\hline
\end{tabular}




\section{Non-Obese}

\begin{tabular}{|c|c|c|c|c|}
\hline \multirow{2}{*}{ Group } & \multicolumn{3}{|c|}{ SSI } & P-Value \\
\hline & & \multicolumn{2}{|c|}{ Not Present } & \multirow{3}{*}{0.01} \\
\hline$A$ & $\begin{array}{l}\text { esent } \\
31\end{array}$ & \multicolumn{2}{|c|}{134} & \\
\hline$B$ & 14 & \multicolumn{2}{|c|}{144} & \\
\hline \multicolumn{5}{|c|}{$\begin{array}{l}\text { Table-VIII. Stratification for surgical site infection with } \\
\text { regards to BMI }(n=399)\end{array}$} \\
\hline \multirow{2}{*}{$\begin{array}{l}\text { Type of } \\
\text { Operation }\end{array}$} & \multirow[b]{2}{*}{ Group } & \multicolumn{2}{|c|}{ SSI } & \multirow{2}{*}{$\begin{array}{l}P \text { - } \\
\text { value }\end{array}$} \\
\hline & & Present & $\begin{array}{c}\text { Not } \\
\text { present }\end{array}$ & \\
\hline \multirow{2}{*}{ Hemicolectomy } & $A$ & 11 & 38 & \multirow{2}{*}{0.34} \\
\hline & $B$ & 6 & 35 & \\
\hline \multirow{2}{*}{$\begin{array}{l}\text { Subtotal } \\
\text { Colectomy }\end{array}$} & $A$ & 9 & 41 & \multirow{2}{*}{0.88} \\
\hline & B & 9 & 38 & \\
\hline \multirow{2}{*}{$\begin{array}{l}\text { Transverse } \\
\text { Colectomy }\end{array}$} & $A$ & 5 & 31 & \multirow{2}{*}{0.72} \\
\hline & B & 4 & 32 & \\
\hline \multirow{2}{*}{ Sigmoidectomy } & A & 4 & 22 & \multirow{2}{*}{0.01} \\
\hline & B & 0 & 38 & \\
\hline \multirow{2}{*}{$\begin{array}{l}\text { Colostomy } \\
\text { reversal }\end{array}$} & $A$ & 8 & 30 & \multirow{2}{*}{0.003} \\
\hline & B & 0 & 37 & \\
\hline
\end{tabular}

Table-IX. Stratification for surgical site infection with regards to type of operation $(n=399)$

\section{Age: $15-50$ years}

\begin{tabular}{|l|c|c|c|}
\hline \multirow{2}{*}{ Group } & \multicolumn{2}{|c|}{ Anastomotic Leakage } & P-Value \\
\cline { 2 - 3 } & Present & Not Present & \\
\hline A & 2 & 123 & 1.01 \\
\hline B & 2 & 117 & \\
\hline
\end{tabular}

\section{Age: $\mathbf{5 1 - 7 5}$ years}

\begin{tabular}{|c|c|c|c|}
\hline \multirow{2}{*}{ Group } & \multicolumn{2}{|c|}{ Anastomotic Leakage } & P-Value \\
\hline & Present & Not present & \multirow{3}{*}{0.27} \\
\hline A & 3 & 71 & \\
\hline B & 1 & 79 & \\
\hline
\end{tabular}

\section{Male}

\begin{tabular}{|l|c|c|c|}
\hline \multirow{2}{*}{ Group } & \multicolumn{2}{|c|}{ Anastomotic Leakage } & P-Value \\
\cline { 2 - 3 } & Present & Not Present & \\
\hline A & 2 & 87 & 0.71 \\
\hline B & 3 & 93 & \\
\hline
\end{tabular}

\section{Female}

\begin{tabular}{|l|c|c|c|}
\hline \multirow{2}{*}{ Group } & \multicolumn{2}{|c|}{ Anastomotic Leakage } & P-Value \\
\cline { 1 - 3 } & Present & Not Present & \\
\hline A & 3 & 107 & 0.09 \\
\hline B & 0 & 103 & \\
\hline
\end{tabular}

Table-XI. Stratification for anastomotic leakagewith regards to gender $(n=399)$
Present

\begin{tabular}{|l|c|c|c|}
\hline \multirow{2}{*}{ Group } & \multicolumn{2}{|c|}{ Anastomotic Leakage } & P-Value \\
\cline { 1 - 3 } & Present & Not Present & \\
\cline { 1 - 3 } A & 3 & 42 & 0.02 \\
\hline B & 0 & 78 & \\
\hline
\end{tabular}

\section{Not Present}

\begin{tabular}{|l|c|c|c|}
\hline \multirow{2}{*}{ Group } & \multicolumn{2}{|c|}{ Anastomotic Leakage } & P-Value \\
\cline { 2 - 3 } & Present & Not present & \multirow{2}{*}{0.46} \\
\hline A & 2 & 152 & \\
\hline B & 3 & 118 & \\
\multicolumn{2}{|c|}{$\begin{array}{r}\text { Table-XII. Stratification for anastomotic leakage with } \\
\text { regards to diabetes mellitus (n=399) }\end{array}$} \\
\multicolumn{2}{|c}{} \\
\hline
\end{tabular}

\section{Obese}

\begin{tabular}{|l|c|c|c|}
\hline \multirow{2}{*}{ Group } & \multicolumn{2}{|c|}{ Anastomotic Leakage } & P-Value \\
\cline { 1 - 3 } & Present & Not present & \\
\hline A & 1 & 33 & 0.26 \\
\hline B & 0 & 41 & \\
\hline
\end{tabular}

\section{Non-Obese}

\begin{tabular}{|l|c|c|c|}
\hline \multirow{2}{*}{ Group } & \multicolumn{2}{|c|}{ Anastomotic Leakage } & P-Value \\
\cline { 1 - 3 } & Present & Not present & \\
\hline A & 4 & 161 & 0.74 \\
\hline B & 3 & 155 & \\
\hline
\end{tabular}

Table-XIII. Stratification for anastomotic leakage with regards to $\mathrm{BMI}(n=399)$

\begin{tabular}{|c|c|c|c|c|}
\hline \multirow{2}{*}{$\begin{array}{c}\text { Type of } \\
\text { Operation }\end{array}$} & \multirow{2}{*}{ Group } & \multicolumn{2}{|c|}{$\begin{array}{l}\text { Anastomotic } \\
\text { Leakage }\end{array}$} & \multirow{2}{*}{$\begin{array}{c}\text { P. } \\
\text { Value }\end{array}$} \\
\hline & & Present & $\begin{array}{c}\text { Not } \\
\text { Present }\end{array}$ & \\
\hline \multirow{2}{*}{ Hemicolectomy } & $A$ & 0 & 49 & \multirow{2}{*}{--} \\
\hline & $B$ & 0 & 41 & \\
\hline \multirow{2}{*}{$\begin{array}{l}\text { Subtotal } \\
\text { Colectomy }\end{array}$} & A & 1 & 49 & \multirow{2}{*}{0.32} \\
\hline & B & 0 & 47 & \\
\hline \multirow{2}{*}{$\begin{array}{l}\text { Transverse } \\
\text { Colectomy }\end{array}$} & A & 1 & 35 & \multirow{2}{*}{1.00} \\
\hline & $\mathrm{B}$ & 1 & 35 & \\
\hline \multirow{2}{*}{ Sigmoidectomy } & $A$ & 1 & 25 & \multirow{2}{*}{0.78} \\
\hline & $\mathrm{B}$ & 1 & 37 & \\
\hline \multirow{2}{*}{$\begin{array}{l}\text { Colostomy } \\
\text { reversal }\end{array}$} & A & 2 & 36 & \multirow{2}{*}{0.57} \\
\hline & $B$ & 1 & 36 & \\
\hline
\end{tabular}

Table-XIV. Stratification for anastomotic leakage with regards to type of operation $(n=399)$ 


\section{DISCUSSION}

Mechanical bowel preparation (MBP) before any elective large gut surgery is in common practice from decades. It is done in order to prevent postop complications like infections; but there is nothing in support of this practice in the literature, still it is a common practice and done frequently in almost all the surgical facilities.

We planned this randomized controlled trial to compare the frequency of infectious complications between mechanical bowel preparation and no preparation in elective colonic surgery. So that we may justify the results in a way that either omission of mechanical bowel preparation makes a difference in terms of reducing infectious complications or it will make no difference at all.

In this study, mean age in Experimental group was $45.98 \pm 13.36$ years in Experimental group and $47.52 \pm 13.21$ years in Control group, $44.72 \%(n=89)$ in Experimental group and $48.24 \%(n=96)$ in Control group were male whereas $55.28 \%(n=110)$ in Experimental group and $51.76 \%(n=103)$ in Control group were females. Comparison of surgical site infection in both groups was done, it shows that $18.59 \%(n=37)$ in Experimental group and $9.55 \%(n=19)$ in Control group had SSI while $81.41 \%(n=162)$ in Experimental group and $90.45 \%(n=180)$ in Control group bad no SSI, $\mathrm{p}$ - value was calculated as 0.009 showing a significant difference. Comparison of surgical anastomotic leakage in both groups was done, it shows that $2.51 \%(n=5)$ in Experimental group and $1.51 \%(n=3)$ in Control group had anastomotic leakage, $p$ - value was calculated as 0.47 showing insignificant difference.

A recent research done by Kumar $A$, et al suggest that if MBP is not done, healing of anastomosis is not disturbed and there is no change in the risk of leakage.[6] This signifies that there is no statistically significant difference in the outcome of use of MBP compared to the outcome of cases done without preparation. In this study, wound infection was seen in $12 \%$ cases in experimental group and in $11 \%$ of controls without bowel preparation. ${ }^{6}$ The findings of our study are contrary to this study. Another study done by Stefano Scabini ${ }^{7}$, rate of infectious complications were found to be $20.0 \%$ after mechanical preparation of bowel versus $11.0 \%$ after no preparation in colonic surgery. This study reported that MBP in elective colonic surgery may not be required. These findings are in agreement with our study.

Alison S McCoubrey ${ }^{9}$ searched the literature and in his review article reached a conclusion that many researchers have reported and recommended large gut surgeries without any pre-op bowel preparation to be safe and may not be required; although if some circumstances it can be valuable like in the presence of any tumor or if in surgeries requiring colonoscopy during the gut surgery. Still to change a clinical practice evidences are not sufficient; a lot of research still need to be done.

Slim et $\mathrm{al}^{10}$ reported similar results but he studied in reverse order; he reported that cases with preop bowel preparation showed more leaks from the anastomotic site compared to the ones not receiving the preparation; along with more risk of infection and failure of surgery, thus increasing the hospital stay (all these results were not significant). The conclusion of his study was in favor of not preparing gut before surgery but this was not statistically significant.

Very few trials are done in this regard comparing the efficacy of not preparing gut before surgery with gut preparation before surgery; two studies have shown ${ }^{11}$ Willie-Jorgensen et $\mathrm{al}^{11}$ found no trend in either direction. But Guenaga et $\mathrm{al}^{12}$ reported that 'no MBP' had a better outcome and this was not statistically significant. It is logically better as it is difficult to perform anastomosis with rectum full of stools. Guenaga et $\mathrm{a}^{12}$ reported that many patients with small tumor also undergo radiotherapy for bowel preparation before gut surgery.

However, in our setup, we found outcome of no MBP was better compared to mechanical bowel preparation in elective colonic surgery in terms of post-operative infectious complications. 


\section{CONCLUSION}

We concluded from all our data that after elective colonic surgery outcome without any complication or with minimal complication was seen with 'no' MBP before surgery and was significantly better as well compared to those in whom mechanical bowel preparation (MBP) was used. Further clinical trials should be done on larger scale to change this practice.

Copyright $@ 15$ Oct, 2019.

\section{REFERENCES}

1. Güenaga KF, Matos D, Wille-Jørgensen P. Mechanical bowel preparation for elective colorectal surgery. Cochrane Database Syst Rev. 2011; (9):CD001544.

2. Altaee WJ. Comparison between mechanical and non mechanical bowel preparation prior to elective colorectal surgery. Al - Kindy Col Med J. 2011; 7(2):8590.

3. Shogan BD, Carlisle EM, Alverdy JC, Umanskiy K. Do we really know why colorectal anastomoses leak? J Gastrointest Surg. 2013; 17:1698-707.

4. Eskicioglu C, Forbes SS, Fenech DS, Fenech RS. Preoperative bowel preparation for patients undergoing elective colorectal surgery: A clinical practice guidelines endorsed by the Canadian society of colorectal surgeons. Canadian J Surg. 2010; 53(6):2 .

5. Fry DE. Fifty ways to cause surgical site infections. Surg Infections. 2011; 12(6):497-500.
6. Saha KA, Chowdhury F, Jha AK, Chatterjee S, Das A, Banu $P$. The use of mechanical bowel preparation versus no preparation before colorectal surgery: A randomized prospective trial in a tertiary care institute. J Nat Sci Biol Med. 2014: 5(2):8.

7. Scabini S, Rimini E, Romairone E, Scordamaglia R, Damiani G, Pertile D. Colon and rectal surgery for cancer without mechanical bowel preparation: One center randomized prospective trial. World J Surg Oncol. 2010; 8:35.

8. Otchy DP, Crossby ME, Trickey AW. Colectomy without mechanical bowel preparation in the private practice setting. Tech Coloproctol. 2014; 18(1);1.

9. McCoubrey AS. The use of mechanical bowel preparation in elective colorectal surgery. McCoubrey AS. The use of mechanical bowel preparation in elective colorectal surgery. The Ulster Medical Journal. 2007; 76(3):127-30.

10. Slim K, Vicaut E, Panis $Y$, Chipponi J. Meta-analysis of randomized clinical trials of colorectal surgery with or without mechanical bowel preparation. $\mathrm{Br} \mathrm{J}$ Surg. 2004; 91(9):1125-30.

11. Wille-Jorgensen P, Guenaga KF, Castro AA, Matos D. Clinical value of preoperative bowel cleansing in elective colorectal surgery: A systematic review. Dis Colon Rectum. 2003; 46(8):1013-20.

12. Guenaga K, Atallah AN, Castro AA, Matos DD, WilleJorgensen $P$. Mechanical bowel preparation for elective colorectal surgery. Cochrane Database Syst Rev. 2005; 1 (CD001544.pub2).

\begin{tabular}{|c|l|l|l|}
\hline \multicolumn{3}{|c}{ AUTHORSHIP AND CONTRIBUTION DECLARATION } \\
\hline Sr. \# & \multicolumn{1}{|c|}{ Author(s) Full Name } & \multicolumn{1}{|c|}{ Contribution to the paper } & Author(s) Signature \\
\hline 1 & Sabeen Adil & $\begin{array}{l}\text { Data collection, Article } \\
\text { Author. } \\
\text { Proof reading, Collection of } \\
\text { references. } \\
\text { Proof reading. }\end{array}$ \\
\hline 3 & Faiqa Aslam & Muhammad Usman & Pon \\
\hline
\end{tabular}

